\title{
HIGHSTAND SEA-LEVEL IN THE HOLOCENE INFERRED FROM BURIED PEAT AND DIATOM ASSEMBLAGES FROM NORTH COAST OF THE YELLOW SEA, CHINA
}

\author{
FANG, J. ${ }^{1}-\mathrm{LI}, \mathrm{Y}^{2}{ }^{2}-\mathrm{GUAN}, \mathrm{X} .^{2^{*}}-\mathrm{HU}, \mathrm{K} .^{2^{*}}$ \\ ${ }^{1}$ School College of Geography and Environmental Science, Tianjin Normal University, Tianjin \\ 300387, China \\ ${ }^{2}$ School of Ocean Sciences, China University of Geosciences, Beijing 100083, China \\ *Corresponding authors \\ e-mail:guanxy@cugb.edu.cn (Guan,X.); huke@cugb.edu.cn (Hu, K.)
}

(Received $20^{\text {th }}$ May 2019; accepted $10^{\text {th }}$ Sep 2019)

\begin{abstract}
Understanding the sea-level change in the geological past is helpful for the future coastal protection. Information of sea-level changes has been documented in various archives in the coasts. In this study, the well-preserved peat in three representative Holocene ditches in Dayanghe Plain in the Yellow Sea China were investigated using radiocarbon dating and diatom analysis. The widely distributed buried peats at elevation of ca. 2-10 m above sea-level (a.s.l.) in Dayanghe Plain are classified as marsh and limnological peats, which were formed after seawater receding from the drowned ditches. The peat layers lower than $4 \mathrm{~m}$ a.s.l., overlain the marine sediments conformably, correspond to the late-Holocene regression. Timing of the highstand sea-level in North Coast of North Yellow Sea is limited to 61825466 cal. a BP by radiocarbon dating. Shell banks at west of the Dagu Mountain which was at a 7-10 m height were thought not to be indicative of the Holocene highstand sea-level.
\end{abstract}

Keywords: diatom assemblages, sea-level rise, radiocarbon dating, peatland, Yellow Sea

\section{Introduction}

The Yellow Sea is one of margin seas in East China, located at the low-gradient shelf between the Chinese mainland and the Korean Peninsula. Thick sediments have been deposited in the Yellow Sea since the Late Pleistocene (Zheng, 1991), containing rich palaeo-environmental information under the sea-level changes in the geological past (Chappell et al., 1996; Kim and Kennett, 1998; Yokoyama et al., 2001; Chappell, 2002; IPCC, 2007; Liu et al., 2004). A multitude of investigations and research on relative sea-level change and environmental evolution in east China have been carried out during the last half century (e.g. Zhao, 1996). Multiple transgressions since late Pleistocene were defined widely in the Bohai Sea, Yellow Sea and East China Sea. Corresponding to the global sea-level change (Shi et al., 2016), three transgressionregression cycles are identified in the coast stratigraphy (Zhao, 1986; Wang et al., 1986; IOCAS, 1985). The transgression-regression sequences have been studied in the chronology (e.g. Liu et al., 2016; Li et al., 2019; Yi et al., 2013), sedimentary processes (e.g. Yi et al., 2012; Liu et al., 2016; Wang et al., 2015), sea-level change (Yi et al., 2012; Liu et al., 2004; Xue, 2014) and driven factors, e.g. palaeo-climate and environment during the geological past (e.g. IOCAS, 1985; Yi et al., 2012).

The uppermost transgressive succession overlying the widely distributed peat or organic-rich sandy interlayer over the coastal areas in the east marginal seas results from the Holocene sea-level rise. The pattern of the Holocene sea-level has been well studied using benthic foraminiferal and stable isotopic approaches with well-established 
radiocarbon chronology (Kim and Kennett, 1998; Liu et al., 2004). Several approaches have been employed for a well understanding of environmental evolution and sea-level change during the Holocene in North Yellow Sea. Peats and shell bars in the Liaodong coastal stratigraphy are likely to deposit during the Holocene sea-level highstand and then dated using radiocarbon (GIGCAS, 1977; Wang et al., 1991; Gao, 1986, 1992). Environmental evolution was interpreted by pollen (GIGCAS, 1977; Liu, 1992), foraminiferal (Yang, 1985) and archeological record (Shi, 2006). Static tectonic movement or slow subsidence in coast of the North Yellow Sea was proposed in former research, e.g. Xiao (1981), Ding (1958) and Zhao (2000), while some researchers assumed a relatively slow uplifting occurring identified by abrasion terrace which is 250 a.s.l. in Dalian, coastal bars and terraces in Liaodong Peninsula (Liu, 1986; Xia et al, 1986). Although the timing of the Holocene transgression in the North Yellow Sea is well restricted, the transgressive process and height of sea-level highstand are still not precisely confirmed mainly due to lack of stratigraphic correlation and reliable sea-level indicators on the background of tectonic uplifting in the North Coast of the Yellow Sea (Fu et al., 1989, 1995; Wei et al., 1984; Zhong and Chang, 1988; Lu, 1985).

Widely distributed marsh peat in the coastal plain is treated as the marker for sealevel highstand (Shennan and Horton, 2002; Engelhart and Horton, 2012). However, the peat formation could be misunderstood due to lack of identification of the contacting layer. As sensitive to salinity, $\mathrm{pH}$ and temperature, diatom is a well indicator to the water-lain sedimentary environments, such as the coast and lacustrine (Kosugi, 1988; Horton, 1997; Horton et al, 2006, 2007). In this paper, we investigated the wellpreserved peat in the three representative ditches in the Dayanghe Plain, the North Coast of the North Yellow Sea. Diatom analysis was applied to identify the types of peat in the different depths. The timing of the marsh peat, indicating the Holocene sealevel highstand, was determined using radiocarbon dating.

\section{Materials and methods}

\section{Study area}

The Yellow Sea is a margin sea of China with average water depth of 60-80 m. It is covered by seawater due to the subsidence of the Zhe-Min Uplift in the early Quaternary (Jin and Yu, 1978; Qin et al., 1989; Yi et al., 2014), Yellow sea is geographically divided into two parts, the North Yellow sea and the South Yellow sea, by Dabie-Linjin fault zone (Qin et al., 1989). The North Yellow Sea is a semi-enclosed sea surrounded by Shandong peninsula, Liaodong peninsula and Korea peninsula. It is a fault basin during Cenozoic on the base of Jiaoliao palaeo-Uplift. Since the Late Tertiary, regional subsidence and stable sedimentation have occurred in the whole Yellow sea, remarked by process of depression sedimentation (IOCAS, 1985; Qin et al., 1989). Current system in the North Yellow sea contains the Yellow Sea Warm Current (YSWC), which is known as a branch of Tsushima Current, and the coastal currents along Chinese and Korean coasts (Fig. 1a). The tide in the North Coast of the Yellow sea is irregularly semidiurnal in range of $4.08 \mathrm{~m}$ (Qin et al., 1989). Due to the strong tide and the flat terrain, 6-10 km wide tidal flat develops in the coastal area. The sedimentary process is dominated mainly by fluvial and tide currents from alluvial plain, estuary to tidal flat.

The study area is the Dayanghe alluvial plain located in southern Liaodong Peninsula. The plain is divided into several small drowned ditches. Sediments in the 
Dayanghe alluvial plain were mainly transported by two local rivers, the Dayanghe River and the Xiaoyanghe River, both originating in the region of Xiuyan in the North Liaoning Province. The Dayanghe River, with length of $201 \mathrm{~km}$, flows from the northeast direction into study area. While the Xiaoyanghe River, $57.40 \mathrm{~km}$ long, flows from the northwest direction into study area. These two rivers meet in the north of alluvial plain, and turn to the direction of south, pouring into the Yellow Sea. The average slopes of Dayanghe alluvial plain are 0.6 and $0.2 \%$, respectively (Fig. $1 b$ ).

The Holocene stratigraphy in southern Liaodong Peninsula was studied in sedimentology, pollen analysis and radiocarbon dating. Southern Liaodong Peninsula was influenced by transgression in early and mid-Holocene, as a result of the regional sea-level rise to the highstand sea-level, then declining with fluctuation to a stable sealevel as present (GIGCAS, 1977). Timing of high-stand sea level between 8000 and 6000 a BP is mainly determined by dating the widely distributed peat layer and shell bar (GIGCAS, 1977; Wang et al., 1991; Gao, 1986, 1992; Fu et al., 1995). Archeological records in southern Liaodong Peninsula provide the evidence of the Holocene transgression using the shells excavated in archeological sites (Shi, 2006).

The Bohai Sea, Yellow Sea and East China Sea are the three marginal seas of China. Current system in Yellow Sea is shown in Figure la (1. Yellow Sea Warm Current (YSWC), 2. Yellow Sea Coastal Current (YSCC), 3. Taiwan Warm Current (TWC), 4. North Yellow Sea Coastal Current (NYSCC), 5. Zhe-Min Coastal Current (ZMCC), 6. Tsushima Strait Warm Current (TSWC)). Sites of the studied boreholes in the North Coast of the Yellow Sea are shown in Figure $1 b$ (Source of the Digital Elevation Model: http://srtm.csi.cgiar.org/).

\section{Studied boreholes}

To investigate the stratigraphic characteristics in the Early and Middle Holocene in the Dayanghe alluvial plain, three boreholes (referred to as LD-1, LD-2 and LD-3, Fig. 1 b) from Dayanghe plain were drilled with the manual sampling device in the three representative ditches. Elevation of each borehole was measured by using level points on topographical map in scale 1:10 000 (1956 Yellow Sea elevation system) and leveling instrument.

The length of core LD-1 $\left(39^{\circ} 55^{\prime} 32^{\prime \prime N}, 123^{\circ} 13^{\prime} 35^{\prime \prime}\right.$, elevation 4.9 m a.s.l.; Fig. 2) was $550 \mathrm{~cm}$. The top $113 \mathrm{~cm}$ of the core consists of silt, with the upper part in yellowbrown and the lower part in grey-brown. A $37 \mathrm{~cm}$-thick layer contains brown-black peat, which can be recognized widely in this area. The depth of brown-grey clayey silt is from 150-165 cm, while the lower blue-grey layer, containing vegetation debris, is from $165 \mathrm{~cm}$ to $505 \mathrm{~cm}$. The lowest part contains brown silt with breccias (505$550 \mathrm{~cm})$.

Core LD-2 (39 $55^{\prime} 42^{\prime \prime}$ N, $123^{\circ} 39^{\prime} 48^{\prime \prime}$, elevation 6.5m a.s.1.; Fig. 1), $560 \mathrm{~cm}$ long, can be described as follows: 0-205 cm, silt with the upper part $(0-150 \mathrm{~cm})$ in yellowbrown and the lower part $(150-205 \mathrm{~cm})$ in grey-brown; $205-238 \mathrm{~cm}$, brown-grey clay with two thin organic-rich layers; $238-266 \mathrm{~cm}$, brown-black peat layer; $266-505 \mathrm{~cm}$, blue-grey organic-rich silt layer; $505-560 \mathrm{~cm}$, blue-grey medium sand with gravels.

Core LD-3 $\left(40^{\circ} 01^{\prime} 21^{\prime \prime} \mathrm{N}, 123^{\circ} 38^{\prime} 35^{\prime \prime}\right.$, elevation $4.8 \mathrm{~m}$ a.s.l.; Fig. 1$)$, with the length of $400 \mathrm{~cm}$, is described as follows: 0-35 cm, brown-grey silt; $35-86 \mathrm{~cm}$, dark grey clay; $86-123 \mathrm{~cm}$, coarse sand in light grey with gravels; $123-150 \mathrm{~cm}$, peat layer; $150-170 \mathrm{~cm}$, brown-black clay with organic-rich materials; $170-352 \mathrm{~cm}$, silty clay in light blue; $352-$ $400 \mathrm{~cm}$, coarse sand in dark grey with gravels. 


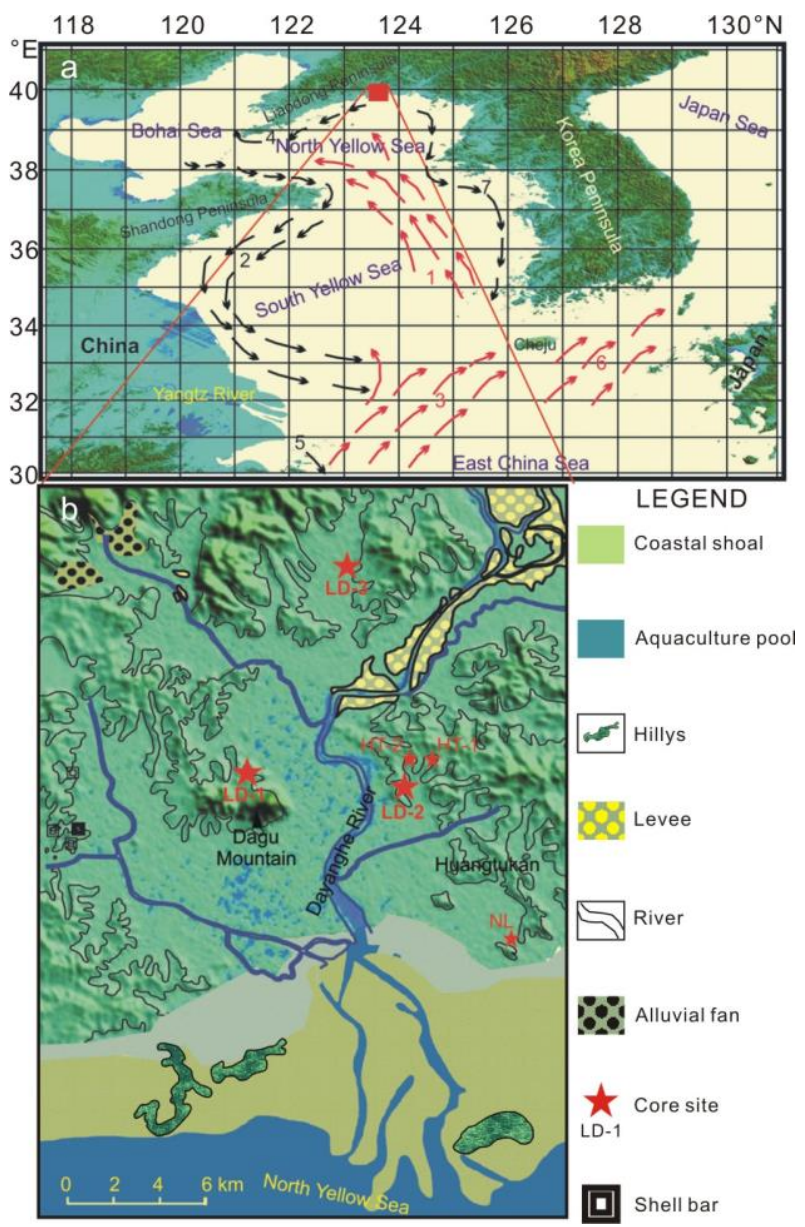

Figure 1. Location of study area. $\boldsymbol{a}$ shows the marginal seas in the East China and the location of the Dayanghe alluvial plain. $\boldsymbol{b}$ shows the geomorphological characteristics of the Dayanghe alluvial plain and the drilling sites.

Several additional boreholes were drilled to investigate the stratigraphy in both three ditches. Peat or black organic-rich clay layers distribute widely in these three ditches, with brownish clay/silt layer overlying and blue clay layer underlying. Peat or black organic-rich layer between $2 \mathrm{~m}$ and $4 \mathrm{~m}$ a.s.l. can be recognized as a mark layer, while peat in $9 \mathrm{~m}$ in ditch LD-1, in $7 \mathrm{~m}$ and $10 \mathrm{~m}$ in ditch LD-2 were distinguished from the mark peat layer not only the appearance of height, but also the contacting layers as the peat layer develops between gravely coarse sand, gravely coarse sand and brownish clay/silt layer in ditch LD-1 and LD-2, respectively.

To compare with the previous research, two boreholes were drilled in region of the Huangtukan (labeled as HT-1 and HT-2, Fig. 1b), which were sampled for investigation of peat layer and diatom analysis and comparison. The elevations of HT-1 and HT-2 are $11.0 \mathrm{~m}$ and $10.8 \mathrm{~m}$, respectively. Peat layer appears in $8.80 \mathrm{~m}$ a.s.l. in core HT-1, with underlying grey peat-clay layer, while in $8.35 \mathrm{~m}$ a.s.l. in core HT-2, with underlying blue-grey medium and coarse sand. Borehole NL was drilled in the modern coast area, at east of the Dayanghe River estuary, for diatom analysis and radiocarbon dating (Fig. 1b). Top elevation of this borehole is $4.7 \mathrm{~m}$ a.s.1., described as: $-0.55--1 \mathrm{~m}$ a.s.1., yellowish medium sand; 1.7 - $-0.55 \mathrm{~m}$ a.s.l., light-grey fine sandy silt and clay interlayers with shell; 4.7-1.7 $\mathrm{m}$ a.s.l., brown-grey silt/light-grey silt. 

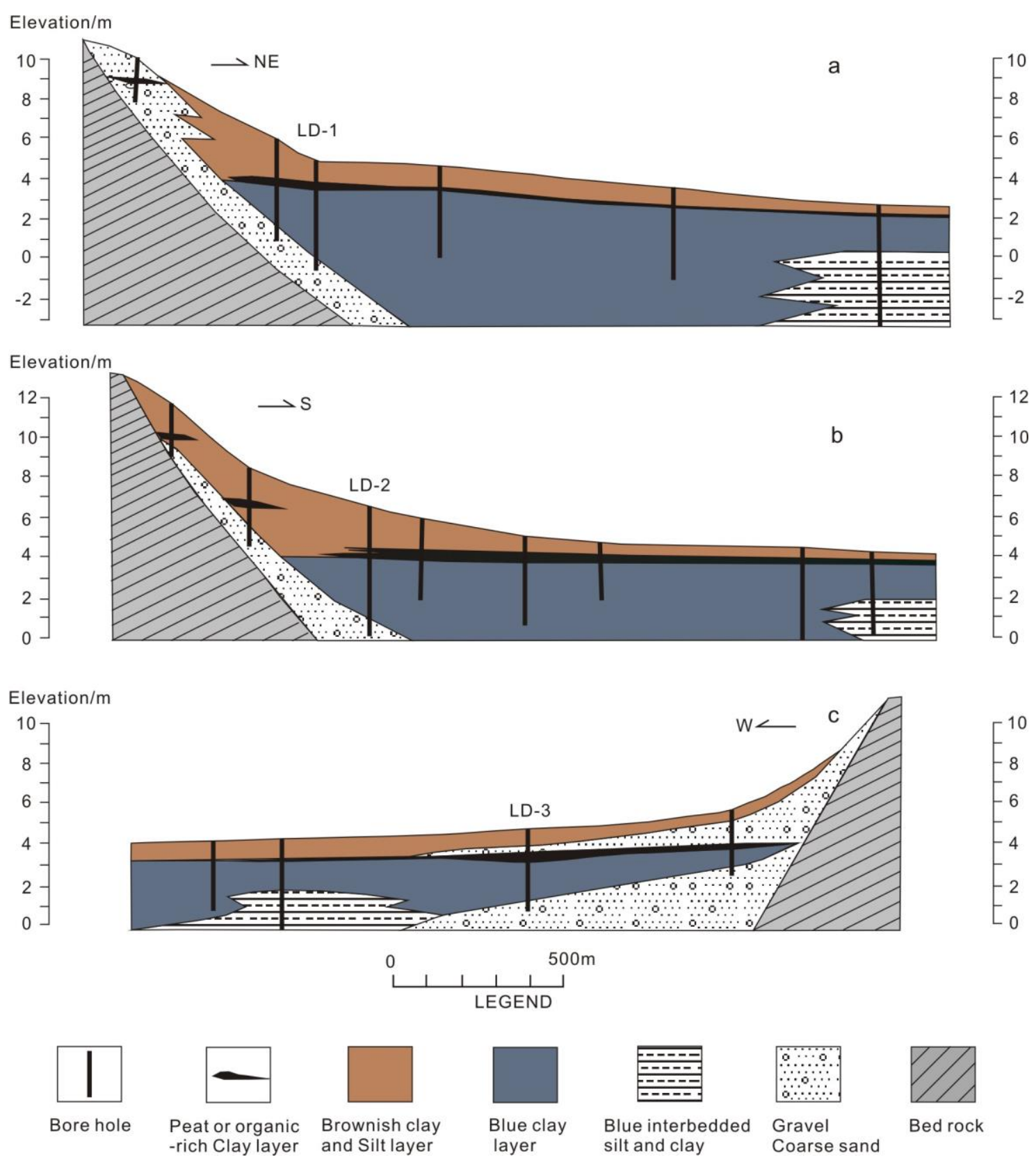

Figure 2. Stratigraphic distribution in three ditches

\section{Radiocarbon dates}

Three samples from the bottom of peat layers were extracted for radiocarbon dating. All radiocarbon dating experiments were conducted at Center for Chronological Research, Nagoya University, using the Accelerator Mass Spectrometry (AMS) method. Radiocarbon dates were calibrated using Calib 5.0.1 (Stuiver et al., 2005). All ages (Table 1) are reported as calibrated calendar ${ }^{14} \mathrm{C}$ ages before AD 1950 (cal BP).

\section{Diatom analysis}

4-6 g sediments were collected at $-20 \mathrm{~cm}$ intervals for diatom analysis. Samples were pre-treated with $30 \% \mathrm{H}_{2} \mathrm{O}_{2}$ to remove organic matter, rinsed with deionized water for 
several times. The coarse sand and gravel fraction were removed by sedimentation method. After abundant precipitation, $1 \mathrm{~mL}$ of liquid was removed to cover slip by transfer pipet, then dried and agglutinated with ground slide by resin. 4-6 slices were made for one sample. Diatom assemblages were identified at $400 \times$ magnification on microscope (smaller individuals at 1000× magnification). At least 200 diatom valves were counted and identified from each slice. Diatom identification and nomenclature were based on KASHINA (1986), KOSUGI (1988) and ANDO and FUJIMOTO (1990). Based on the living environment, three kinds of diatom were classified, as 1) marine-brackish species (M-B), living in marine and inner bay environment under seawater; 2) brackishfresh species (B-F), living in environment influenced by mixture of fresh water and brackish water, but not existing in marine environment; 3 ) fresh species (F), living in the fresh water environments, such as wetland, marsh and river, etc.

Table 1. Radiocarbon date on materials from core $L D-1, L D-2, L D-3$ AND NL

\begin{tabular}{c|c|c|c|c|c|c}
\hline Core & $\begin{array}{c}\text { Samples elevation } \\
\text { a.s.l. (m) }\end{array}$ & Materials & \multirow{2}{*}{$\boldsymbol{\delta}^{\mathbf{1 3}} \mathbf{C}$} & \multirow{2}{*}{$\begin{array}{c}\text { Conventional } \\
\text { age/a BP }\end{array}$} & & \multicolumn{2}{|c}{ Calibrated age/a cal BP } \\
\cline { 5 - 6 } & & & Intercept & Range \\
\hline LD-1 & 3.40 & Peat & -28.8 & $4721 \pm 160$ & 5466 & $5286-5645$ \\
LD-2 & 3.84 & Peat & -27.9 & $5242 \pm 140$ & 6052 & $5895-6208$ \\
LD-3 & 3.3 & Peat & -26.4 & $4707 \pm 140$ & 5466 & $5288-5603$ \\
NL & -0.5 & Shell & -1.2 & $5784 \pm 180$ & 6182 & $5985-6378$ \\
\hline
\end{tabular}

\section{Results and discussion}

\section{Diatom analysis for core $L D-1$}

Core LD-1 was divided into four diatom assemblage zones (Fig. 3a).

\section{Zone I $(505-330 \mathrm{~cm})$}

Marine-brackish species, including marine species Thalassionema nitzschioides, indicate the open marine environment. Cyclotella stylorum, Paralia sulcata, Actinocyclus spp., Cosinodiscus spp. are indicative of the inner bay environment. Brackish species Diploneis smithii are found in the lower part of blue-grey layer in Zone I. The component of species above reaching 75-95\% is related to a process of transgression that this area was covered by seawater.

\section{Zone II $(505-330 \mathrm{~cm})$}

In Zone II, the marine-brackish species decrease from 94 to $61 \%$, while an increase of brackish-fresh and fresh species from 6 to $40 \%$ indicate a process of regression with a w seawater influence and a stronger influence by freshwater.

\section{Zone III $(163-150 \mathrm{~cm})$}

Various species appear in Zone III. 20\% are marine-brackish, while the fresh and brackish-fresh species reach $80 \%$, including Pinnularia spp. (29\%), which inhabited in marsh environment, and the fresh-brackish species Rhopalodia gibberula, $14 \%$ of total species. The dominating assemblages with mixture of fresh and brackish-fresh taxa are commonly observed in the wetland environment influenced by seawater. 


\section{Zone IV $(150-133 \mathrm{~cm})$}

In Zone IV, constrained to the peat layer, nearly all taxa were fresh species, with wetland species Pinnularia spp. (34-47\%), Eunotia spp. (3-8\%) and Cymbella spp. (5$11 \%$ ), and fresh benthonic species Hantzschia amphioxys (6-11\%). The diatom assemblages in the peat layer showed a wetland environment influenced rarely by seawater.
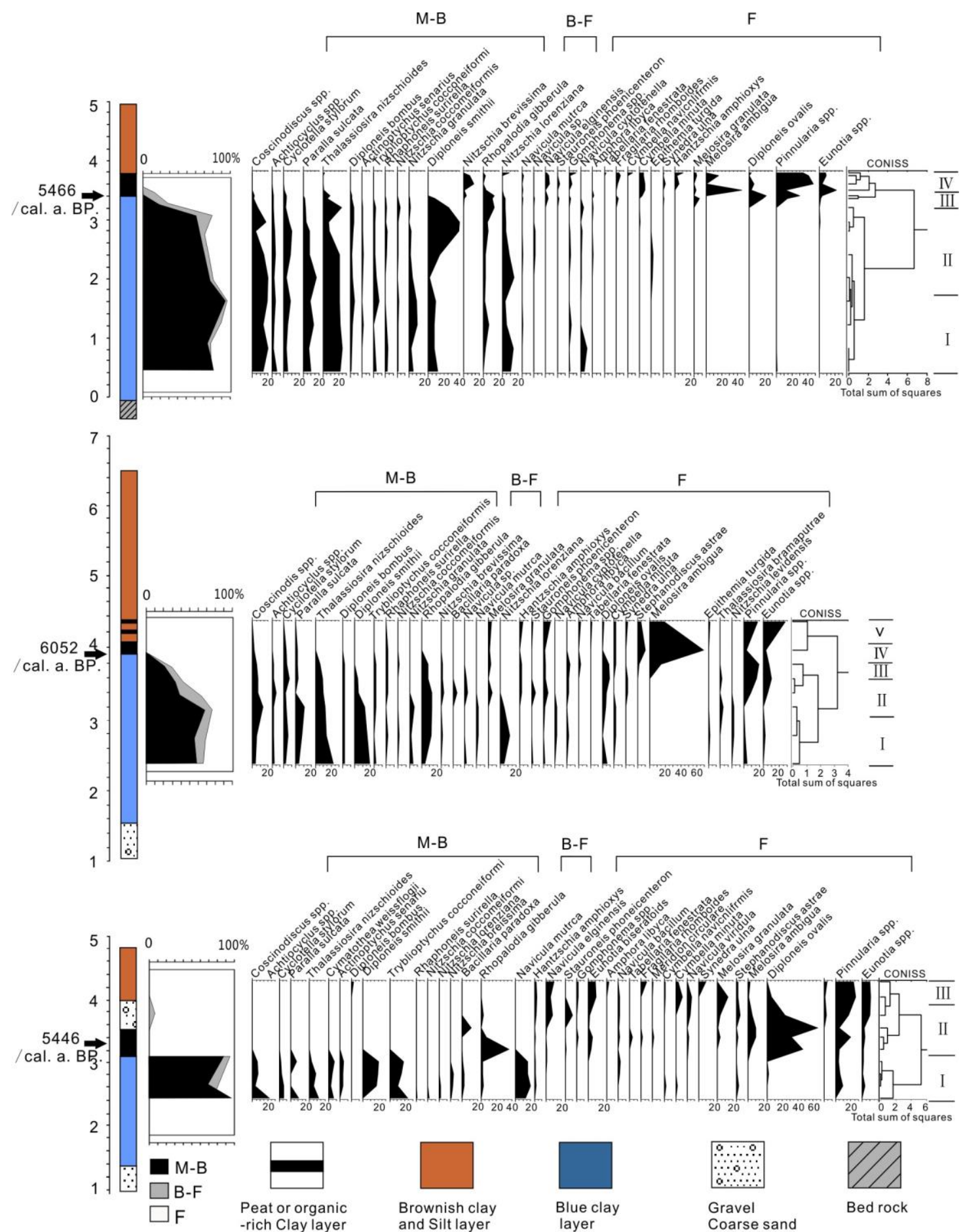

Figure 3. Result of diatom analysis for three cores, $\boldsymbol{a}, \boldsymbol{b}$ and $\boldsymbol{c}$ are correspondence of $L D-1, L D$ 2 and $L D-3$, respectively. 


\section{Diatom analysis for core $L D-2$}

Core LD-1 was divided into five diatom assemblage zones (Fig. 3b).

Zone I $(430-350 \mathrm{~cm})$

The main taxa are marine-brackish species (57-66\%), accompanied by fresh species (22$32 \%)$ and fresh-brackish species (5-12\%). Among the taxa, Percentage of the marine indicator taxa, Thalassionema nitzschioides, was 12-14\%, while marine-brackish species such as Diploneis smithii were reaching 12-18\%, indicating a drowned ditch environment.

\section{Zone II $(350-290 \mathrm{~cm})$}

With the same lithological characteristics as Zone I, Zone II contained nearly the same diatom assemblages, with a notably declining trend of marine-brackish species from $66 \%$ to $34 \%$ and increase of fresh and fresh-brackish species. The indicators of the marsh and wetland such as Pinnularia spp. and Eunotia spp. with a percentage of 15-20\%, show there was a declining trend of sea-level, accompanied by environment changing from drowned ditches to salty marsh.

\section{Zone III (290-266 cm)}

In Zone III, constrained to upper part of blue-grey peaty clay layer, the marinebrackish species declined to $21 \%$, with an increase of fresh species to $69 \%$. The marsh and wetland indicators such as Pinnularia spp. and Eunotia spp. were with a percentage of 29\%. The limnological environment indicator Melosira ambigua, known as a plankton species, appeared within this interval with a percentage of $16 \%$, indicating a salty marsh environment covered by water.

\section{Zone IV $(266-230 \mathrm{~cm})$}

Zone IV is the peat layer, containing only $4 \%$ marine species and nearly $95 \%$ were fresh species. The marsh and wetland indicators such as Pinnularia spp. and Eunotia spp. declined to $6 \%$, accompanied by limnological environment taxa such as plankton Melosira ambigua and Stephanodiscus astrae with a drastic increase to $87 \%$. It suggests that the environment changed from a marsh wetland to limnological environment.

\section{Zone V $(230-205 \mathrm{~cm})$}

The brown-black peat and brown-grey silt occur in Zone V. Pinnularia spp. and Eunotia spp. increased rapidly, with the percentage of $18 \%$ and $28 \%$, respectively. Melosira ambigua and Stephanodiscus astrae decline to $19 \%$ and 5\%, respectively. We infer that the environment changed from fresh lake to marsh and wetland covered by shallow water.

\section{Diatom analysis for core $L D-3$}

Three diatom assemblage zones were found in core LD-3 (Fig. 3c).

\section{Zone I (290-170 cm)}

In Zone I, marine-brackish species dominated with a percentage of 68-98\%. There was an increase trend of Diploneis smithii from $16 \%$ to $35 \%$, indicating a period of inner bay environment covered by shallow seawater. 
Zone II was characterized by conspicuous increase of fresh species without marinebrackish species, although constrained to a combination of peaty clay, peat and coarse sand with gravels layers. A fresh lake environment appeared in this period, characterized by a significant increase of fresh limnological taxa such as Melosira ambigua and Stephanodiscus astrae with percentage of 24-67\%.

\section{Zone III $(80-35 \mathrm{~cm})$}

In Zone III, Melosira ambigua and Stephanodiscus astrae met a clear declining trend to $3-5 \%$, with Pinnularia spp. and Eunotia spp. increasing rapidly reaching $35 \%$. A stream environment indicator Gamphonena spp. appeared in this zone (6-11\%), indicating a wetland environment influenced by stream.

\section{Diatom analysis for core HT-1 and HT-2}

Peat, grey peat in core HT-1 and blue-grey medium and coarse sand in core HT-2 were employed for diatom analysis. Results from both the cores show that few diatom species exist in underlying layers with small amount of fresh species such as Pinnularia spp., Eunotia spp. and Hantzschia amphioxys.

\section{Diatom analysis for core $N L$}

Overlying the yellowish medium sand to $4.2 \mathrm{~m}$ a.s.1., M-B species play a dominate role, containing Coscinodiscus excentricus, indicator of coastal environment and inner bay, and Thaiassionema nitzschioides, indicator of coastal environment, with significant percentages of $33-25 \%$ and $10-28 \%$, respectively. A declining trend of the number of diatoms above $4.2 \mathrm{~m}$ a.s.1. is observed, with the dominant species indicative of freshwater environment, such as Pinnularia spp. and Eunotia spp. (18-37\% and 18$25 \%$, respectively).

\section{Diatom species and covered water change}

The diversity of diatom assemblage in Core LD-1 shows that the environment changed gradually from the bottom to the top, as marine-brackish species dominated in the lower part, while fresh-brackish and fresh species dominated in the upper part, suggesting that the environment varied from drowned ditch covered to salty marsh, and then to fresh wetland and marsh. The gradual change shows that the sediments provide continuous environment records, documenting the waning of seawater influence. Diatom species in the peat layer were mostly fresh indicators, especially inhabited in marsh and wetland environment, while the underlying part contained brackish-fresh species with gradual increase of brackish-marine diatoms, which indicated that these organic-rich materials were formed in a marsh environment with sea level regressed in the semi-enclosed drowned ditch. Hence, the base of peat layer which contacted with underlying layer can be used as the turning point from sea-level highstand to regression, with $3.40 \mathrm{~m}$ a.s.l. The calibrated radiocarbon age of $5466 \mathrm{cal}$. a B.P., indicating that the shoreline retreated from 5466 a B.P. from the position of core LD-1 with elevation of ca. $3.40 \mathrm{~m}$ a.s.l.

Sedimentary environment change can be identified from the vertical change of diatom assemblages in Core LD-2. From the bottom of LD-2, five diatom assemblage 
zones were constrained to drowned ditch covered by seawater, drowned ditch with shallow seawater, salty marsh, lacustrine bog and wetland, respectively. Similar with LD-1, the peat layer contacted conformably with underlying part, which contained gradual increase of fresh-brackish species from the base to the top, showing a gradual declining of sea level. The radiocarbon date showed that the seawater had regressed from the small drowned ditch since $6052 \mathrm{cal}$. a B.P., in height of $3.84 \mathrm{~m}$ a.s.1.

Without gradual change of the diatom assemblages, the fresh-species dominant peat directly contacted with underlying by marine-brackish sedimentary layer in core LD-3, in disagreement with the cores LD-1 and LD-2. It is likely related to erosion or drastic increase of fresh water level. The elevation of $3.10 \mathrm{~m}$ a.s.l. for the peat layer in core LD-3 is thus not applicable to indicate the sea-level in this site. The radiocarbon date is 5446 cal. a BP for this peat layer.

\section{Peatlands and its implication of the mid-Holocene sea level change}

The Dayanghe Plain is geomorphologically separated into several drowned ditches with a static sedimentary environment. The distribution of the buried peat layers in these three drowned ditches could be recognized from the boreholes. The elevation of the peat layer declines from head to mouth, corresponding to the sea-level regression. Determined by diatom assemblages, this layer is classified as the marsh or limnological peat, rarely influenced by seawater. The distribution of peat in LD-3 ditch indicates that seawater reached to the LD-3 ditch, which is $20 \mathrm{~km}$ to the present estuary, occupying the whole Dayanghe Plain. The lower blue-grey clay layer likely resulted from shallow marine environment during the Early-Middle Holocene. The boundary of peat and the lower blue-grey layer corresponds to seawater regression in the Dayanghe Plain. In the LD-3 ditch, peat and black clay appeared at elevations of $6.4 \mathrm{~m}$ and $9.0 \mathrm{~m}$ a.s.1., whereas the underlain sediment succession contains no marine-brackish species. Therefore, the noncontinuous peat and organic-rich clay in the LD-3 ditch are not result of the Holocene sea-level change.

It demonstrates that the boundary between the peat layer and the blue-grey marine strata is approximately $4 \mathrm{~m}$ a.s.l. in the head of ditches. It is consistent with the mean high tide line at that time. The tidal range in this area is $4.08 \mathrm{~m}$ at present, with mean regional sea-level in $0.36 \mathrm{~m}$ a.s.l. We assume that the situation in mid-Holocene was consistent with present, and the mean sea level could be calculated as: high tide level minus half of the tidal range $(4-4.08 / 2 \mathrm{~m}=1.96 \mathrm{~m})$, which implies that the sea-level was approximately $1.60 \mathrm{~m}$ higher than present. Although one radiocarbon date for the LD-3 peat is doubtful to indicate the seawater regression due to the unconformable contact between the peat and the underlain silt layer, the age results from cores LD-1 and LD-2 suggested the Holocene regression started during 6052-5466 cal. a BP. It challenges the outcomes from the previous studies. The buried peat at the height of $8 \mathrm{~m}$ a.s.l. in Huangtukan area has been thought to be related to the high sea-level since 7840 cal. a BP. Similarly, the shell banks in the west Dagu Mountain at height of 7$10 \mathrm{~m}$ a.s.l. have been considered as the result of sea-level rise and tectonic uplifts, which was 3-6 m higher than result from buried peat and diatom analysis. Moreover, the upper grey silt layer in core NL, deposited in the coastal environment, was dated back to 6182 cal. a BP using the shell collected from the bottom of this layer. It suggests that seawater reached to the Dayanghe Plain not before ca. 6000 cal. a BP. More evidence was provided by diatom analysis from cores drilled in Huangtukan area. Buried peat was found in core HT-1 and HT-2, in height of 8.80 and $8.50 \mathrm{~m}$ a.s.l., respectively. 
Only several diatom species inhabiting in fresh water were found in lower parts of both two cores. Therefore, the peat in the Huangtukan area is not indicative of sea-level change during the Holocene.

The sea-level of $1.60 \mathrm{~m}$ higher than the present during the Holocene sea-level highstand is also supported by the results of the previous research in Japanese coastal areas, e.g. Hokkaido, Tsugaru Plain, Osaka Bay and Tamagawa. They suggested that the sea-level highstand occurred during 6000-5500 cal. a B.P. The sea-level was 0-5 $\mathrm{m}$ higher than the present (UMITSU, 1994). Therefore, the height of highstand sea-level in the North Coast of the Yellow Sea in the Middle Holocene (6052-5466 cal. a BP) is constrained to ca. $1.60 \mathrm{~m}$ a.s.l. by radiocarbon dating and diatom analysis approaches.

\section{Conclusions}

Using diatom assemblage analysis and radiocarbon dating approaches, the sea-level highstand and the timing of the sea-level highstand termination in the North Coast of the Yellow Sea were investigated. We draw our conclusions as follows.

(1) The widely distributed buried peat, at elevation of 2-10 $\mathrm{m}$ a.s.l. in the Dayanghe Plain was classified as marsh and limnological peat, which formed after seawater regressing from the drowned ditches. Only the peat layer below $4 \mathrm{~m}$ a.s.l., contacting the lower marine section conformably, were related to regression.

(2) The peatland at $<4 \mathrm{~m}$ a.s.l. formed during the period of $6182-5466$ cal. a BP, indicating the Holocene highstand sea-level was $1.60 \mathrm{~m}$ higher than the present.

(3) According to the diatom assemblages in the studies cores, the shell banks at west of Dagu Mountain at height of 7-10 $\mathrm{m}$ is not indicative of sea-level change. The shell banks are also excluded as sea-level indicator as they are much higher than the results of the regional sea-level investigations.

(4) It is necessary to investigate the notches, terraces and buried peat in the adjacent areas for comparison to better understand the Holocene sea-level change.

\section{REFERENCES}

[1] Ando, K., Fujimoto, K. (1990): Paleo-environmental history and sea-level records based on the diatom assemblages in the middle part of the Arakawa lowland, Central Japan. The Quaternary Research 29: 427-437.

[2] Chappell, J. (2002): Sea level changes forced ice breakouts in the Last Glacial cycle: new results from coral terraces. - Quaternary Science Reviews 21: 1229-1240.

[3] Chappell, J., Omura, A., Esat, T., McCulloch, M., Pandolfi, J., Ota, Y., Pillans, B. (1996): Reconciliaion of late Quaternary sea levels derived from coral terraces at Huon Peninsula with deep sea oxygen isotope records. - Earth and Planetary Science Letters 141: 227236.

[4] Ding, X. (1958): Problem uplifting or subsidence in coastal zone, Liaoning. - China Quaternary Research 1: 160-165.

[5] Engelhart, S. E., Horton, B. P. (2012): Holocene sea level database for the Atlantic coast of the United States. - Quaternary Science Reviews 54: 12-25.

[6] Fu, W., Li, G., Wei, C. (1989): Late Quaternary shoreline migration along the eastern coast of Liaodong Peninsula. - Oceanologia et Limnologia Sinica 20: 252-262.

[7] Fu, W., Wang, G., Liu, G. (1995): Peat deposition and sea level change in Holocene, Liaoning. - Journal of Oceanography of Huanghai \& Bohai Seas 13: 23-32. 
[8] Gao, F. (1986): The relation between formation of peat in seaside area of Bohai Sea and North Yellow Sea and sea level fluctuation since the Late Wuerm-glaciation. - Scientia Geographica Sinica 6: 56-63.

[9] Gao, S., Li, Y., Liu, G. (1992): Sedimentary characters and sea level change recorded by sand and gravel bank-lagoon system in coastal zone, Liaoning. - Acta Geographica Sinica 47: 129-137.

[10] GIGCAS (1977): The natural environment changes last10000 years in South Liaoning Province. - Science in China (Series A) 6: 603-614.

[11] Horton, B. P. (1997): Quantification of the indicative meaning of a range of Holocene sea-level index points from the western North Sea. - Doctoral dissertation, Durham University.

[12] Horton, B. P., Corbett, R., Culver, S. J., Edwards, R. J., Hillier, C. (2006): Modern saltmarsh diatom distributions of the Outer Banks, North Carolina, and the development of a transfer function for high resolution reconstructions of sea level. - Estuarine, Coastal and Shelf Science 69: 381-394.

[13] Horton, B. P., Zong, Y., Hillier, C., Engelhart, S. (2007): Diatoms from Indonesian mangroves and their suitability as sea-level indicators for tropical environments. - Marine Micropaleontology 63: 155-168.

[14] IOCAS (1985): Bohai Sea Geology. - Science Press, Beijing.

[15] IPCC (2014): Climate Change 2014: Impacts, Adaptation, and Vulnerability (edited by Field, C. B., Barros, V. R. et al.) - Cambridge University Press, New York.

[16] Jin, X., Yu, P. (1978) Preliminary study on geomagnetic field and tectonics of continental shelf of the East China Sea. - Marine Sciences 3: 94-96.

[17] Kashina, K. (1986): Holocene successions of diatom fossil assemblages in alluvium, and those relations to paleo-geographical changes. - Geographical Review of Japan 59: 383403.

[18] Kim, J. M., Kennett, J. P. (1998): Paleoenvironmental changes associated with the Holocene marine transgression, Yellow Sea (Hwanghae). - Marine Micropaleontology 34: 71-89.

[19] Kosugi, M. (1988): Class ification of living diatom assemblages as the indicator of environments, and its application to reconstruction of paleoenvironments. - The Quaternary Research 27: 1-20.

[20] Li, G., Li, P., Liu, Y., Qiao, L., Ma, Y., Xu, J., Yang, Z. (2014): Sedimentary system response to the global sea level change in the East China Seas since the last glacial maximum. - Earth-Science Reviews 139: 390-405.

[21] Li, Y., Tsukamoto, S., Shang, Z., Tamura, T., Wang, H., Frechen, M. (2019): Constraining the transgression history in the Bohai Coast China since the Middle Pleistocene by luminescence dating. - Marine Geology: 416.

[22] Liu, G., Han, M. (1986): New discovery of residual coastal sediments in Dalian. - Acta Oceanologica Sinica 6: 793-796.

[23] Liu, G., Gao, S., Li, Y. (1992): Sedimentary environment and sea level fluctuation in Holocene, Dalian area. - Geographical Research 11: 38-45.

[24] Liu, J., Wang, H., Wang, F., Qiu, J., Saito, Y., Lu, J., Zhou, L., Xu, G., Du, X., Chen, Q. (2016): Sedimentary evolution during the last $\sim 1.9 \mathrm{Ma}$ near the western margin of the modern Bohai Sea. - Palaeogeography, Palaeoclimatology, Palaeoecology 451: 84-96.

[25] Liu, J. P., Milliman, J. D., Gao, S., Cheng, P. (2004): Holocene development of the Yellow River's subaqueous delta, North Yellow Sea. - Marine Geology 209: 45-67.

[26] Lu, Y. (1985): Displacement of shoreline and neotectonic movement in the eastern China during the Holocene. - Proceedings of Collection of Quaternary Coastline Symposium, China, pp. 76-87.

[27] Qin, Y. S., Zhao, Y. Y., Chen, L. R., Zhao, S. L. (1989): Geology of the Yellow Sea. China Ocean Press, Beijing. 
[28] Shennan, I., Horton, B. (2002): Holocene land-and sea-level changes in Great Britain. Journal of Quaternary Sciences 17: 511-526.

[29] Shi, B. (2006): Archeological record for high stand sea level in Holocene, Liaodong Peninsula. - Sichuan Cultural Relics: 37-41.

[30] Stuiver, M., Reimer, P. J., Reimer, R. W. (2005): CALIB 5.0.1. WWW Program and Documentation. - www.calib.org.

[31] Umitsu, M. (1994): Late Quaternary Environment and Landform Evolution of Riverine Coastal Lowlands. - Kokon-Shoin, Tokyo.

[32] Wang, F., Li, J., Chen, Y., Fang, J., Zong, Y., Shang, Z., Wang, H. (2015): The record of mid-Holocene maximum landward marine transgression in the west coast of Bohai Bay, China. - Marine Geology 359: 9-95.

[33] Wang, Q., Li, F., Li, Y., Gao, X. (1986): Shoreline Changes in West-Southern Coastal Plain of the Bohai Sea Since 150 ka. - In: Qin, Y. S., Zhao, S. (eds.) Late Quaternary Sea-Level Changes. China Ocean Press, Beijing, pp. 62-71.

[34] Wang, S., Zhang, W. (1991): Preliminary discussion on coastal change in Liaodong Peninsula during Holocene. - Progress of Geomorphology and Quaternary 1986: 199201.

[35] Wei, C., Li, G., Fu, W. (1984): A preliminary study on the development of the mud-flat coast of the north Yellow Sea. - Marine Geology \& Quaternary Geology 4: 35-42.

[36] Xia, H., Zhang, X. (1986): Coastal topography and the reflection of neotectonic movement in coastal zone in Liaodong Peninsula. - Seismology and Geology 3: 40-49.

[37] Xiao, R., Tang, C. (1981): Differentiation of marine geomorphology in Liaodong Peninsula. - Journal of Northeast Normal University 1981: 83-90.

[38] Xue, C. (2014): Missing evidence for stepwise postglacial sea level rise and an approach to more precise determination of former sea levels on East China Sea Shelf. - Marine Geology 348: 2-62.

[39] Yang, W., Lin, J. (1985): Preliminary Notes on Holocene Transgression in the Southeast Coast of Liaodong Peninsula. - Chinese Journal of Geology 2: 196-201.

[40] Yi, L., Yu, H., Ortiz, J. D., Xu, X., Qiang, X., Huang, H., Shi, X., Deng, C. (2012): A reconstruction of late Pleistocene relative sea level in the south Bohai Sea, China, based on sediment grain-size analysis. - Sedimentary Geology 281: 88-100.

[41] Yi, L., Lai, Z., Yu, H., Xu, X., Su, Q., Yao, J., Wang, X., Shi, X. (2013): Chronologies of sedimentary changes in the south Bohai Sea, China: constraints from luminescence and radiocarbon dating. - Boreas 42: 267-284.

[42] Yi, L., Ye, X., Chen, J., Li, Y., Long, H., Wang, X., Du, J., Zhao, S., Deng, C. (2014): Magnetostratigraphy and luminescence dating on a sedimentary sequence from northern East China Sea: Constraints on evolutionary history of eastern marginal seas of China since the Early Pleistocene. - Quaternary International 349: 16-326.

[43] Yokoyama, Y., Esat, T. M., Lambeck, K. (2001): Coupled climate and sea-level changes deduced from Huon Peninsula coral terraces of the last ice age. - Earth and Planetary Science Letters 193: 579-587.

[44] Zhao, G., Liu, X., Ma, S., Tian, S., He, S. (2000): Crustal deformation of coastal zone based on tidal record in China. - Seismology and Geology 22(4): 371-378.

[45] Zhao, S. (1986): Transgression and Coastal Changes in Bohai Sea and Its Vicinities since the Late Pleistocene. - In: Yunshan Qin, S. Z. (ed.) Late Quaternary Sea-Level Changes. China Ocean Press, Beijing.

[46] Zhao, X. (1996): China Climate and Sea-Level Change: Trend and Influence. - Shandong Science and Technology Press, Shandong.

[47] Zheng, G. (1991): Quaternary Geology in the Yellow Sea. - Science Press, Beijing.

[48] Zhong, Y., Gao, C. B. (1988): Sea level changes in the Holocene and crustal movement in the past 5000 years in the Liaodong Peninsula. - Marine Sciences 1: 4-8. 